Andrews University

Digital Commons @ Andrews University

\title{
The Melodic Structure And Form Of Norwegian Lullabies (Bansuller) From The Valleys Of Valdres, Gudbrandsdalen, And Osterdalen
}

Elbjorg Keyn Lundstrom

Andrews University

Follow this and additional works at: https://digitalcommons.andrews.edu/theses

Part of the Music Commons

\section{Recommended Citation}

Lundstrom, Elbjorg Keyn, "The Melodic Structure And Form Of Norwegian Lullabies (Bansuller) From The Valleys Of Valdres, Gudbrandsdalen, And Osterdalen" (1987). Master's Theses. 15.

https://dx.doi.org/10.32597/theses/15

https://digitalcommons.andrews.edu/theses/15

This Thesis is brought to you for free and open access by the Graduate Research at Digital Commons @ Andrews University. It has been accepted for inclusion in Master's Theses by an authorized administrator of Digital Commons@ Andrews University. For more information, please contact repository@andrews.edu. 


\section{INFORMATION TO USERS}

The most advanced technology has been used to photograph and reproduce this manuscript from the microfilm master. UMI films the text directly from the original or copy submitted. Thus, some thesis and dissertation copies are in typewriter face, while others may be from any type of computer printer.

The quality of this reproduction is depender.i upon the quality of the copy submitted. Broken or indistinct print, colored or poor quality illustrations and photographs, print bleedthrough, substandard margins, and improper alignment can adversely affect reproduction.

In the unlikely event that the author did not send UMI a complete manuscript and there are missing pages, these will be noted. Also, if unauthorized copyright material had to be removed, a note will indicate the deletion.

Oversize materials (e.g., maps, drawings, charts) are reproduced by sectioning the original, beginning at the upper left-hand corner and continuing from left to right in equal sections with small overlaps. Each original is also photographed in one exposure and is included in reduced form at the back of the book. These are also available as one exposure on a standard 35mm slide or as a 17" x 23" black and white photographic print for an addiiional charge.

Photographs included in the original manuscript have been reproduced xerographically in this copy. Higher quality $6^{\prime \prime} \times 9^{\prime \prime}$ black and white photographic prints are available for any photographs or illustrations appearing in this copy for an additional charge. Contact UMI directly to order.

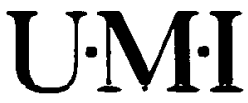

University Microlilms international

A Bell \& Howell Information Company

300 North Zeeb Road. Ann Arbor. MI 48106-1346 USA

$313 / 761-4700 \quad 800 / 521-0600$ 
Oxder Number 1885497

The melodic structure and form of Norwegian lullabies (binsuller) from the valleys of Valdres, Gudbrandsdalen, and Daterdalen

\author{
Lundström, Elbjørg Keyn, M.A.
}

Andrews University, 1987

Copyright @1989 by Lundström, Elbjørg Keyn. All rights reserved.

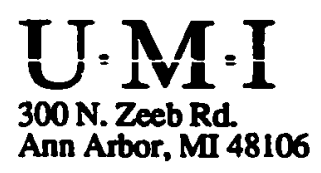

Reproduced with permission of the copyright owner. Further reproduction prohibited without permission. 


\title{
Andrews University
}

school of Graduate studies

\section{THE MELODIC STRUCTURE AND FORM OF NORWEGIAN LULLABIES (BẢNSULLER) FROM THE VALLEYS OF VALDRES, GUDBRANDSDALEN, AND ØSTERDALEN}

\author{
A Thesis \\ Presented in Partial Fulfillment \\ of the Requirements for the Degree \\ M.A. in Music
}

by

Elbjørg Keyn Lundström

August 1987

Reproduced with permission of the copyright owner. Further reproduction prohibited without permission. 


\title{
THE MELODIC STRUCTURE AND FORM OF NORWEGIAN LULLABIES (BÃNSULLER) FROM THE VALLEYS OF VALDRES, GUDBRANDSDALEN, AND ØSTERDALEN
}

\author{
A thesis \\ presented in partial fulfillment \\ of the requirements for the degree \\ Master of Arts
}

by

Elbjørg Keyn Lundström

APPROVAL BY THE COMMITTEE:
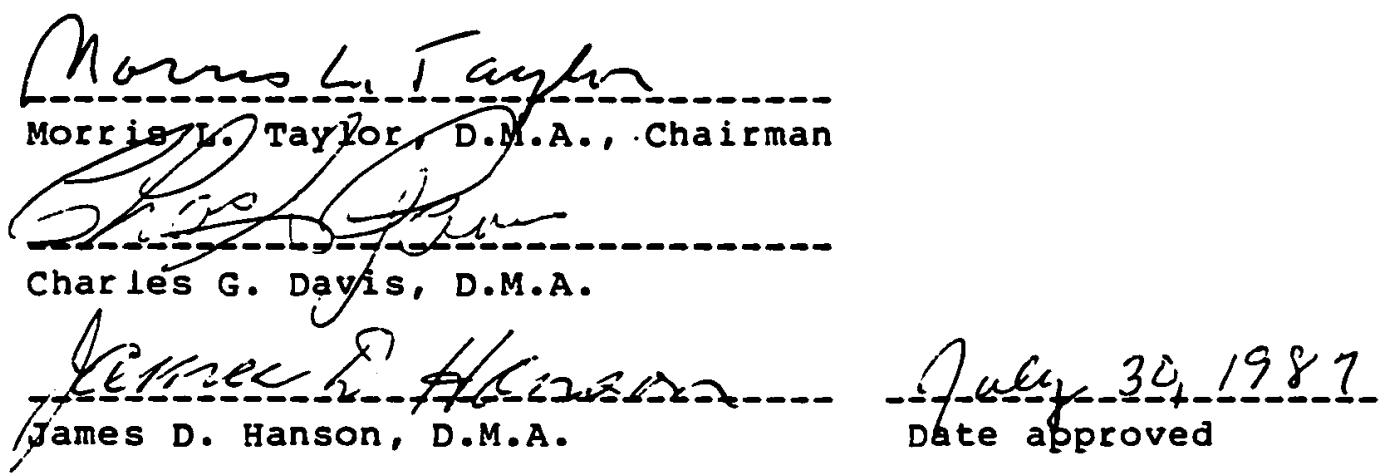
(c) Copyright by Elbjørg Keyn Lundström

All Rights Reserved

Reproduced with permission of the copyright owner. Further reproduction prohibited without permission. 
TABLE OF CONTENTS

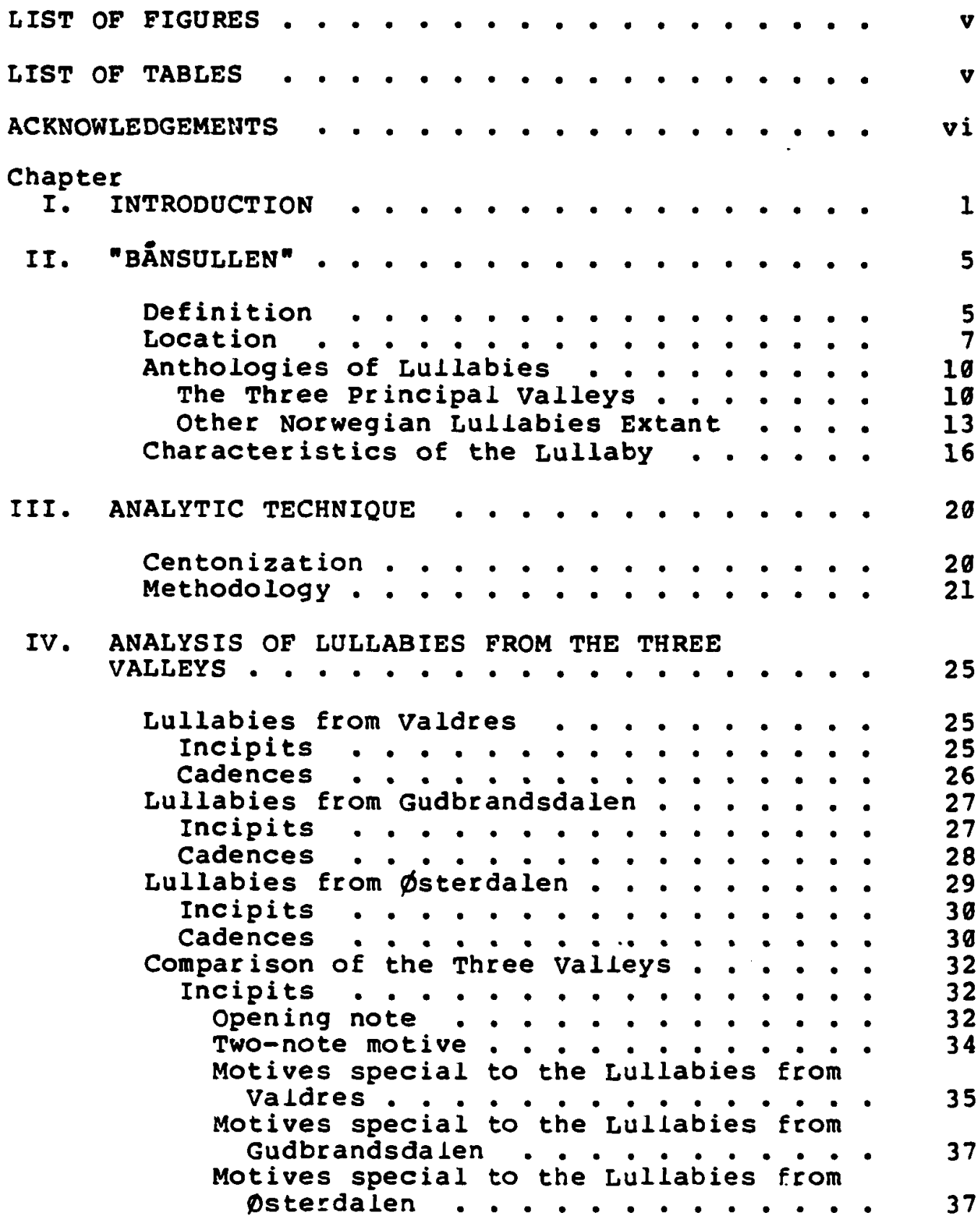

i i 1 


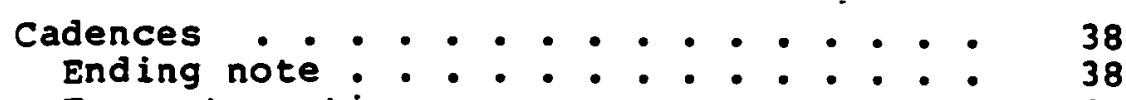

Two-note motive . . . . . . . . . . 40

Motives special to the Lullabies from

valdres . . . . . . . . . . . . 41

Motives special to the Lullabies from

Gudbrandsdalen ........... . 42

Motives special to the Lullabies from

Østerdalen ............... . 42

v. CONCLUSION . . . . . . . . . . . . . . . 44

APPENDIX

1. List of Collected Lullabies... . . . . . 49

2. Supplementary Information of Known Published Lullabies... . . . . . . . . . . . 53

3. Abbreviation and Numbering of Analyzed

Lullabies... . . . . . . . . . . 55

SELECTED BIBLIOGRAPHY . . . . . . . . . . . . 57

Reproduced with permission of the copyright owner. Further reproduction prohibited without permission. 


\section{LIST OF FIGURES}

1. Map of Norway Showing the Areas from where Lullabies Are Collected . . . . . . . .

2. Title Page to First Edition of Lindeman's Collection Aldre og Nyere Norske

Fjeldmelodier $(1853-67)^{-}$. . . . . . . 12

3. Example of a Numbered Phrase . . . . . . . 23

$$
\text { LIST OF TABLES }
$$

1. Percentage of Use of Various Pitches as opening Note in Lullabies from the Three valleys.? 33

2. Percentage of Use of Various Pitches as Ending Note in Lullabies from the Three valleys.. 


\section{ACKNOWLEDGEMENTS}

It is my pleasure to acknowledge the help and encouragement of the following people, without whose help and time this study may never have been completed. My heartfelt thanks go to my husband, Claes Iundström, for the great patience and helpfulness he has showed me in my work. Thanks also to my advisor, Dr. Morris L. Taylor, for all the time and help he has given me in the completion of this research. A special thanks also to Dr. C. Warren Becker for his guidance through the earlier phases of this study; and to Dr. Charles G. Davis and Dr. James D. Hanson who served on my thesis examining committee.

A work like this, which deals with Norwegian Eolk music, but which has been done mainly in the United States, requires a great deal of help from various people. Appreciation goes to the University Library of Oslo, from where most of the material for my research has been gathered; to the Music Materials Center at Andrews University, for letting me freeiy use their sources; and to Dr. A. Rae Holman for giving me access to the private library of her late husband, Dr. Hans-Jørgen Holman. I am very much indebted to Dr. Hans-Jorgen Holman for his 
help and guidance when I first started working on this thesis.

And finally, besides many more who rightly would

deserve a word of appreciation, I want to thank my

Eather, Eivind keyn, for his encouragement and all the

help he has given me especially in sending necessary

material over from Norway. 


\begin{abstract}
THE MFLODIC STRUCTURE AND FORM OF NORWEGIAN LULLABIES (BÅNSULLER) FROM THE VALLEYS OF VALDRES, GUDBRANDSDALEN, AND ØSTERDALEN
\end{abstract}

by

Elbjorg Keyn Lundström

Chairman: Morris L. Taylor

Reproduced with permission of the copyright owner. Further reproduction prohibited without permission. 


\title{
ABSTRACT OF GRADUATE STUDENT RESEARCH
}

Thesis

\section{Andrews University}

Department of Music

\begin{abstract}
Title: THE MELODIC STRUCTURE AND FORM OF NORWEGIAN LULLABIES (BÂNSULLER) FROM THE VALLEYS OF VALDRES, GUDBRANDSDALEN, AND ØSTERDALEN

Name of researcher: Elbjorg Keyn Lundström

Name and degree of faculty advisor: Morris L. Taylor, D.M.A. Date completed: August 1987
\end{abstract}

\section{Problem}

This study analyzes a significant group of lullabies collected from three of the principal valleys in Norway. A detailed analysis may show the extent of centonization within the lullabies and may reveal aspects of the tonal inflection of these melodies. 
Method

The study gives a general description of the lullaby. It also presents an annotated listing of collections and a summary of previous studies done in this area. With the help of traditional techniques and computer technology, the motives from 154 melodies were analyzed.

\section{Results}

The analysis resulted in the discovery that the lullabies consist to a large degree of certain motives that are common to all three valleys. However, the melodies from each valley have certain characteristics which are unique to that valley or which appeared very seldom in the other two valleys.

\section{Conclusions}

To a large extent these lullabies utilize the technique of centonization and have their own tonal inflection. 


\section{CHAPTER I}

\section{INTRODUCTION}

Norway has a rich heritage of vocal and

instrumental music. Today much of this folk music tradition is disappearing. A hundred and fifty years ago, when the folk music collectors first started their work, there were many types of vocal and instrumental folk music.

Within the vocal folk music tradition one can still find dance songs, ballads, cattle calls, religious folk tunes, and lullabies; and instrumental music in the form of fiddle tunes is still alive today.

The cattle call [lokk] of the shepherd girl [budeie] and the tunes of the shepherd boy [gjetergutt on the shepherd's horn [lur] and ram's horn [bukkehorn] are disappearing together with the milieu of the summer mountain farm [seter]. Medieval ballads are still being sung all over the country by many folk dance groups, but they are rarely found as part of a living [folk] tradition. On the other hand, there are numerous lullabies [bånsuller]: unpretentious little tunes which for many generations have been used to sing babies to sleep. I

Within the vocal tradition of Norwegian folk music, the lullaby [bånsull] has played a significant

${ }^{1}$ Liv Greni, "Folkemusikk," Norsk musikk [Folk music, Norwegian Music] (Os10: studier i Norge, 1968), p. 32. Translation mine. 
role. At a time when so much of the older folk tradition in music seems to have disappeared, it is one of the few types of folk melodies still alive today, because of the important function of the lullaby in everyday life; i.e., to "Iull" the little one to sleep.

In order to pinpoint similarities and differences Hampus Huldt-Nystrom did a study on instrumental fiddle tunes of Norway, comparing them with fiddle tunes of sweden. He called his book Det nasjonale tonefall [The "national inflection"1.2 The late Hans-Jørgen Holman, professor of music at Andrews University, gives a definition of this concept in an article about centonization technique in the vocal folk music of Norway.

A great deal of interest has been centered around the "national inflection" (det nasjonale tonefall) in Norwegian folk music and its influence on Norwegian art music from the nineteenth century to the present. A somewhat elusive concept, the national inflection can perhaps best be thought of as the sum total of the elements that constitute the characteristics of a body of national music. . . . It includes elements of recurrent integrating rhythmic and melodic materials (centos) as well as the underlying scale foundation. if such exists, and is seen in their impact on establishing a tonal or modal structure. Also, it incorporates intonation, vibrato, tone quality, variations in tempo, and textual declamation, the more subtle--and not easily measurable--properties which are usually not refleçted in our conventional system of musical notation. 3

${ }^{2}$ Hampus Huldt-Nystrøm, Det nasjonale tonefall [The national inflection] (Os 10: Universitetsforlaget, 1966).

${ }^{3}$ Hans-Jorgen Holman. "Centonization Technique in the Vocal Folk Music of Norway," Michigan Academician 15 (Spring 1983): 333 . 
Although much has been written about the melodic form and structure of different types of Norwegian folk music, and of the national inflection as a whole, no extensive research has yet been done in the area of the lullabies. One study has dealt with the motives and formulas in a group of lullabies from setesdal, but as yet nobody has done a thorough research on a larger group of these melodies in order to study their tonal inflection. Do Iullabies from various parts of Norway have their own tonal inflection? To what extent do the lullabies utilize motives and formulas, using the technique of centonization?

The purpose of this study was to analyze a significant group of lullabies collected from the three valleys of Valdres, Gudbrandsdalen, and osterdalen, in order to establish what consti:utes their unique tonal inflection. The main thrust of the analysis is to expolore the use of centonization within the melody of these lullabies. An investigation of various other characteristics is to discover identifying features of the melodies from these three valleys. Traditional analytic techniques combined with computer technology are used to search for possible answers to these questions. Because the lullabies are such an important part in Norwegian folk tradition both of today and yesterday, they should therefore be the subject of a more thorough investigation. Since the lullaby is most likely the 
first kind of music a child is exposed to, it would be reasonable to presume that these melodies might color the child's further musical experience.

Reproduced with permission of the copyright owner. Further reproduction prohibited without permission. 
CHAPTER II

"BĀnsullen"

\section{Definition}

"Bănsull" is the Norwegian name for a little simple melody to be sung to a small child. The word is dialectal. "Bàn" means child, and "sull" means a short simple melody.

$$
\text { Traditionally the "bånsull" was sung to put a }
$$

small child to sleep. Over the years these songs have acquired many other functions. Some melodies are used to make the child laugh, while others are used to stop the child Erom crying. 1 In Norsk Folkemusikksamling [Norwegian Folk Music Collection], the melodies are divided into three categories: (1) Bănsuller [Lullabies]. (2) Bånsuller med tekst [Lullabies with text], and (3) Barneviser [Children's songs]. 2 since these three groups of songs are used interchangeably in daily life,

${ }^{1} \emptyset y s t e i n$ Gaukstad, Toner fra Valdres (Tones from Valdres] (Gjøvik: Mariendáls Boktrykkeri A/S, 1973), p. 198.

2Tom H. Halvorsen et al.. "En undersøkelse av bănsuller fra: Lom, Sogn, Rana, Trysil, Voss, Sør-Aurda I" [An examination of luliabies from: ....] (Musikk mellomfag [2nd degree in music]. University of Oslo, 1973). p. I. 
alı categories have been included in this research, and for practical reasons they are mentioned under the same name: Iullaby.

The texts in most of the lullabies are about people, nature, and things close to the daily life of the child. Life in the "saeter" (summer farms up in the mountains) influenced the theme of many a lullaby. The lyrics are, therefore, often about animals. Some tunes resemble the calls by the shepherd as he herds the animals in the mountains, or the cattle calls used by the shepherdess to get the animals back from the fields to the farm in the evenings. Some lullabies have themes from the world of fairy tales; others are more like riddles. Many songs which were used to lull the little ones to sleep actually have no real text, only a few nonsense syllables; i.e.." "sull-lu11."

Apart from the cattle calls, hardly any other folk music expression has as old an origin as lullabies. 3 They became an important part of everyday life. The cattle calls and shepherd tunes are disappearing together with the summer mountain farm and its culture; however, the lullabies are still alive today and in use all around the country.4 They still serve their function, both by the cradle and in upbringing the child. A hundred and

3 Arne Bjørndal, Norsk folkemusikk [Norwegian folk music) (Bergen: A.s Lunde CO. ForIag, I952), p. 200.

${ }^{4}$ Liv Greni, "Folkemusikk," p. 32. 
fifty years ago, when the folk music collectors first started their work, there were hundreds of lullabies in common use. But, unfortunately, even these types of folk melodies are now rapidly decreasing in number.

\section{Location}

The lullabies in this study are taken from many geographical areas. To give a clearer view of these areas a map of Norway is included (Fig. 1). Half of the melodies, the lullabies that are to be analyzed, are gathered from three principal valleys in Norway: (1) Valdres, (2) Gudbrandsdalen lGudbrand's valley], and (3) Dsterdalen [Eastern valley]. Together the valleys constitute a large part of Eastern Norway. Each of the valleys is quite broad with a river running through, bounded by steep hillsides. Gudbrandsdalen and Фsterdalen are U-shaped, from ancient times founded by glaciers; while valdres is V-shaped, founded by rivers. Although none of these valleys has been isolated from the outside world, the people living in a certain valley have developed their own special characteristics. This can be noticed by differences in language (dialects), culture, and music.

valdres is a picturesque valley which served as the old highway between Eastern and Western Norway. According to 申ystein Gaukstad in Toner fra Valdres [Tones from Valdres], the valley was active in trade with oslo and other surrounding towns. Folk dancing, which each 


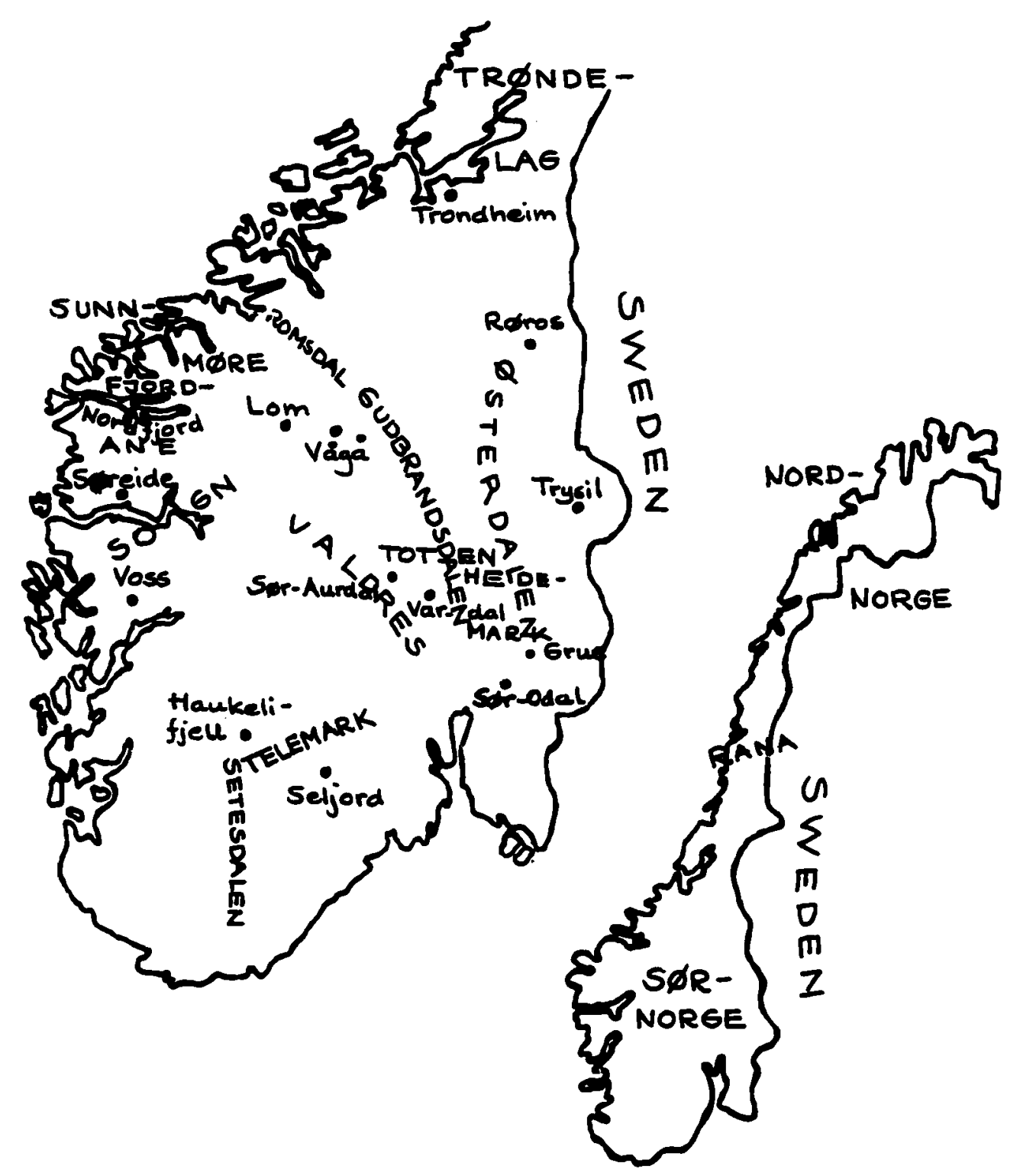

Fig. 1. Map of Norway showing the areas from where lullabies are collected. 
summer took place in the mountains, brought the peopla from the surrounding valleys together. The festivals also fostered an exchange of artistic and musical values. soldiers and students brought home impulses from outside, especially from the Danish-Norwegian capital. Copenhagen. 5

Gudbrandsdalen is a stately valley situated between valdres and $\phi s t e r d a l e n$. Like Valdres there was a lively connection with the outside world. Influence on the folk music of this open valley has come from all directions, from Romsdalen, Sunnmore, the Fjords, Valdres, Hedmark, фsterdalen, and Røros. 6 More than the areas to the west, the folk music of Gudbrandsdalen shows the influence of the cities, of the educated people such as the clergy, the teachers, the sheriff, etc.., and even to a certain degree swedish music. 7

Furthest east of the three valleys, right on the border of sweden, is Østerdalen. With its deep forests, this valley is not as open as the neighboring valley, Gudbrandsdalen. The more somber, melodic melodies, and the preference for the minor mode, typical of this area, may reflect the nature of the valley; but even though the

${ }^{5}$ Gaukstad, p. 101 .

${ }^{6}$ ole M. Sandvik, Folkemusikk i Gudbrandsdalen [Folk music in Gudbrandsdalen], 2nd ed. TOslo: Forlaget Johan Grundt Tanum, 1948), p. 12 .

7 Idem, Norsk Eolkemusikk [Norwegian folk music] (Kristiania: steenske forlag, 1921), p. 13 . 
music seems a bit introverted, it does not mean that the people in the valley have been isolated. Osterdalen had a lively connection with its neighboring valleys. Certain routes over to Gudbrandsdalen and Opdal were short, and a busy trade was maintained with Hedmark. Some areas had contact with Røros, others with parts of Sweden (areas that belonged to Norway until the midseventeenth century but are now part of sweden). Among the lullabies taken from this valley, one melody recorded in särna, Sweden, in the 1920s, is originally Norwegian. Another couple of lullabies are supposed to have been derived from våge in Gudbrandsdalen. 8 The collections from these three valleys constitute the main body of the material which has been analyzed, the results of which are discussed in a later chapter. A search for other Norwegian lullabies resulted in approximately 150 additional lullabies. Most are of a more recent origin than the collections already mentioned.

\section{Anthologies of Lullabies}

The Three principal Valleys

The collection of folk music from the valleys of Valdres, Gudbrandsdalen, and osterdalen stretches over a period of more than one hundred years. The earliest

8 Idem, (Os lo: For laget Johan Grundt Tanum, 1943; reprint ed.. Oslo: Noregs Boklag, 1979), pp. 29, 80. 
recorded melodies from Valdres were by the Danish collector Andreas P. Berggren (1801-80), from the middle 1846s. Several other collectors followed him. Ludvig $M$. Iindeman (1812-87), who has to be regarded as one of the pioneers in the gathering of folk music, toured valdres in 1848,1862 , and 1865. The melodies from his 1848 tour were gathered in a collection called Aeldre og nyere norske fjeldmelodier [Earlier and more recent Norwegian mountain melodiesl. (see fig. 2.) This book contains more than six hundred melodies of various types from different parts of Norway. 9

Later transcriptions were made by Catharinus Elling (1906-08 and 1916), Ole Mørk Sandvik (1916), Erik Eggen (1929, 1930, and 1931), sigurd Islandsmoen (1934, 1946, and 1949), and others. Gaukstad has selected from all these sources, transcribed some tape recordings made by the Norwegian Broadcasting Corporation, Per Goplerud, and himself, and gathered them all in his book Toner fra Valdres. It contains seventy-two lullabies, arranged according to variant relations. 10

The main collector of folk music from Gudbrandsdalen and Østerdalen is Sandvik (1875-1976), an active folk music researcher. He has written several books with collections of folk music from different parts

$$
\begin{aligned}
& { }^{9} \text { Gaukstad, pp. } 9,103 . \\
& 10_{\text {Ibid., p. } 100 .}
\end{aligned}
$$




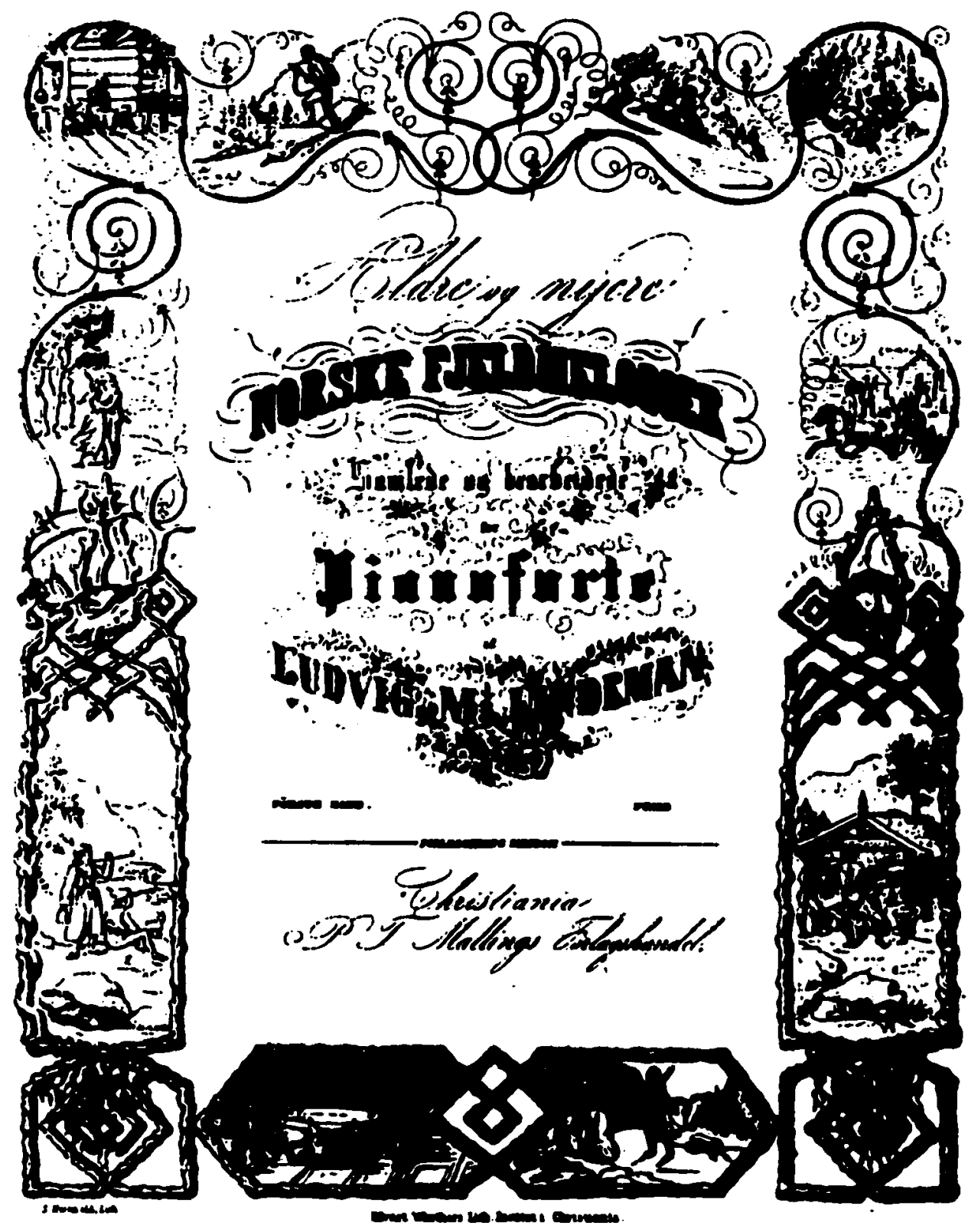

Fig. 2. Title page to the first edition of Lindeman's collection Aldre of Nyere Norske Fjeldmelodier (1853-67) 
of Norway, working since the early 1900s. The lullabies from Gudbrandsdalen are found in his book Eolkemusikk fra Gudbrandsdalen [Folk music from Gudbrandsdalen], which was first printed in 1919. The second edition, published in 1948, contains his own folk music transcriptions plus a supplement of a part of Lindeman's collection of folk melodies from this area. The lullabies collected are chiefly taken from the northern parts of the valley. By counting the different variants of a melody, there are forty-eight tunes altogether.

The melodies and their variants from the third valley. Фsterdalen, are thirty-four in number. They were gathered a few years later than the tunes from Gudbrandsdalen, most of them in the 1920s. These Iutlabies are found in Sandvik's book фsterdalsmusikken [Music of Østerdalen]. which was first printed in 1943. A reprint edition was published posthumously in 1979.

Other Norwegian Lullabies Extant Apart from the melodies already published in Toner fra Valdres, eight more lullabies from Lindeman's collection, Aeldre og nyere norske fjeldmelodier, have been gathered. These tunes are from seljord and. Haukelifjell in Telemark, Valdres, and Trondheim.11

${ }^{11}$ Ludvig M. Lindeman, Aeldre og Nyere norske fjeldmelodier [Earlier and more recent Norwegian mountain melodies], TChristiania: P. T. Malling's Forlag, 1853-67, 1907; reprint ed.. Os10: Norsk Musikkforlag A/S \& Lindemans Legat, 1983). 
Elling (1858-1942), a keen folk music researcher and another of Gaukstad's sources, is the collector of fifteen more melodies from Lom in Gudbrandsdalen. Toten in Oppland, Telemark, Sunnmpre, and Nordfjord. These tunes were gathered under the period between 1908 and 1925. Nearly all are taken from two of his books: Norske folkeviser [Norwegian folk tunes] and vore folkemelodier [Our folk melodies].12

Twenty melodies published by A. Hole in 1930 are from Vardal in oppland (from vardal bygdebok); two

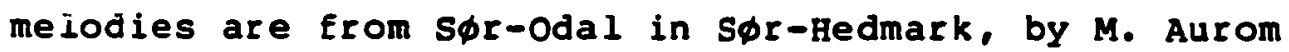
(1942); and one melody is from Grue in Glamdalen, by $s$. Holt $(1946-47)$.

A larger collection of forty-one lullabies is taken from Trondelag. The melodies are recorded over a period of nearly fifty years $(1928-70)$ and published by Helge Dillan in Folkemusikk i Trondelag (Folk music in Trønde lag ] . 13

Liv Greni, a professor of music at the university of Oslo, has done a study of the melodic formulas in lullabies from setesdal. The material for her study was gathered through the summers of 1950, 1952, and 1956, and the results of her research are discussed in a later

12 (Christiania: Norsk Musikkforlag, 1968-25) and (Christiania: Jacob Dybwad, 1909).

13 (Os 10: Noregs Boklag, 1972). 
chapter.14 From three of Greni's articles on Norwegian folk music, eleven lullabies have been selected to be part of this collection.

The three last collections of melodies are taken

from the written works of eight students at the University of oslo. The studies were done in the fall of 1973 and 1974. One student, Ragnhild E. Paulsen, transcribed five lullabies from Lom in Gudbrandsdalen. These transcriptions were made from tape recordings of variants to melodies found in Sandvik's collection from the 1920s. The purpose of her study was to underline how different the same lullaby can sound in the same part of the country.

Another student, Rachel J. Larsen, went into the Ejords in the Western part of Norway, to søreide, Høyanger commune in Sogn, where she collected several types of vocal folk melodies. It seemed to her that it was the lullabies people remembered best of a1l.15 The final thirty lullabies are part of an analysis done by another six students from the university of Oslo. These lullabies are transcribed tape recordings from the archives of Norsk Folkemusikksamling. These

14 "Bănsuller i Setesdal," Norveg [LuLlabies in Setesdal, Norway], 7, 13; Os10: $19 \overline{60}$.

15 "Bånsuller i levende tradisjon i sфreide" [Lullabies in living tradition in Søreide] (Musikk grunnfag [lst degree in music], University of Oslo, 1974), pp. 1, 2. 
recordings are from six different areas of Norway: Lom in Gudbrandsdalen, Trysil in фsterdalen, Sør-Aurdal in

Valdres, Rana in North of Norway, Voss, and Sogn. These collections contain a large number of the known published lullabies. For complete information on the different collections, see the list in Appendix 1. supplementary material of known published lullabies and recordings of lullabies not included in this research is listed in Appendix 2.

Characteristics of the Lullaby

Historically, the lullabies give some of the most valuable material within the folk music tradition. They span the whole development of vocal folk music. Melodies collected more than a hundred years ago have characteristics which have persisted since ancient times. Examples of this can above all be seen in the use of quarter tones. 16

The quarter tones are actually indeterminate pitches. These seem to have their origin as far back as the Gregorian Chant. 17 There are more than three times as many examples of quarter tones in the lullabies of Gudbrandsdalen than those of Dsterdalen. The tuning of the dulcimer had "half-high" tones on the sixth, seventh, and fourth degree of the scale, the so-called "nature-

${ }^{16}$ Sandvik, Folkemusikk fra Gudbrandsdalen, p. 48 . 17 Idem, Norsk folkemusikk, p. 76. 
scale". This instrument was much played in Gudbrandsdalen and valdres, but not in Dsterdalen.18

Another trace of the ancient origin of the lullaby appears in their tendency towards church modes, pentatonalism, and the predilection for the minor mode. In Dsterdalsmusikken only one lullaby is recorded in pure major. Although some melodies start out in major, they end in minor. In Gudbrandsdalen the major mode is used more frequently, but even there, minor tunes are in the majority. 19 Although the number of major tunes increase the further west one travels, there still seems to be a preference for minor in the rest of the lullabies gathered from other parts of the country. Most of the lullabies were sung unaccompanied; and a few were actually played on an instrument. In the Eastern part of Norway the foremost instrument has been the German violin; however, the flute, the shepherd's horn [lur], the ram's horn [bukkehorn], the dulcimer [ langeleik], and the jew's-harp [munnharpe] have also been in frequent use over the years. Unfortunately, many of these instruments are today regarded as almost antiques. The main instrument in the Western part of Norway is the fiddle [hardingfele]. This instrument has

18 Bjarne Kortsen, 77 Norwegian Lullabies according to Dr. O. M. Sandvik (Bergen: BY the Author, Solbakken 17, 5000 Bergen, 1978), p. 7 .

${ }^{19}$ sandvik, фsterdalsmusikken, p. 28 . 
four strings which may be played with a bow. plus other strings which vibrate sympathetically. The further north one goes, the less instrumental music has been cultivated, although the use of the violin is still noted. The Laps in the very far north, for example, totally lack any form of instrumental music. 20 Like most folk music the lullabies are orally transmitted and are, therefore, subject to change. Many folk singers improvise and seldom sing a melody the same way twice.

For most of the melodies studied in this document, the name of the folk singer is known. Approximately 300 lullabies have been included in this study. The songs of more than 125 different persons have been collected; more than half were women.

The steady rocking of the child in the cradle or in the arms of the folk singer is a determining factor for the usage of metre in the lullabies. The most employed metres are in two-time $(2 / 4$ and $4 / 4)$ and $6 / 8$. These seemed to most efficiently put the child to sleep. But there are quite a few which also use $3 / 4$ time. The range of the melodies is usually quite small. In most lullabies it stretches over a fifth or a sixth. Sometimes it pays a brief visit to the seventh below the

20 Arnt Bakke, "Folkemusikk i Nord-Norge," Ottar: populaere smáskrifter fra Tromso Museum [Folk musicin north of Norway. Ottar: Popular journals from Troms $\phi$ Museum] $13 / 2($ March 1957) : 6 . 
tonic, or the phrase has an upbeat on the dominant below. Sometimes the range is expanded to an octave, or even further in some of the instrumental lullabies. The tonic, fifth, and the third are the most important pitches, and often the melody lacks the sixth and the seventh scale-degrees.

The melody usually moves diatonically. Few large intervals are employed. In the more recent collections, a tendency towards more triadic outline of the melody is prominent, a fact that shows the gradual change within folk music to more contemporary tonality. Especially in the earlier collections, a few ornaments are used to embellish the melodies.

Textually the lullabies are usually sung in the dialect of the different areas. The texts often seem to be the most important factor in determining the melody's form. There seems to be no fixed form among the lullabies, although many are in two or three parts. 21 Quite often the melody is simply constructed. This is probably due to the fact that a complicated tune would fail its main purpose in rocking the child to sleep. The length of the melody varies--some are just a few bars or a couple of phrases; others a longer "composition." over all they are usually short. Many times the melody is made up of a few recurring motives.

\footnotetext{
p. 6 .
}

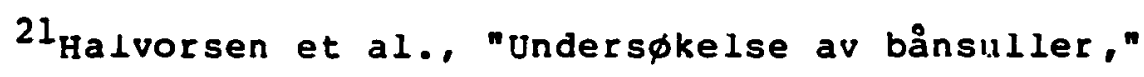


CHAPTER III

\section{ANALYTIC TECHNIQUE}

\section{Centonization}

For a number of years researchers have believed that folk music to a large extent is built on certain formulas or motives. Ole M. Sandvik observed this as early as the $1920 \mathrm{s.l}$

Hans-Jørgen Holman has done some studies on the recurring melodic material (centonization) in Norwegian vocal folk music, especially within the religious folk tunes. He asserts that:

The use of centonization technique in the melodic material found between cadence points--not on ly the melodic material itself--in the vocal folk music of Norway is often very similar to that found in gregorian chant. At times, the recurring melodic material is entif̧ely identical as it appears in different tunes.

The term centonization, comes from Latin and

$$
\text { actually means "patchwork." }
$$

The term is modern, borrowed from poetry by Ferretti in 1934, and has been applied mainly to Gregorian and other chant.

since the 19 th century some scholars have recognized the role played in some music by

${ }^{1}$ Sandvik, Norsk folkemusikk, p. 55.

${ }^{2}$ Holman, "Centonization Technique", p.340. 
traditional aptness rather than originality; the notion of centonization has gradually grown out of this recognition.

Holman also found that:

In the computer printouts involving the folk tunes, a large number of recurring melodic patterns, four to ten or more notes long, are found. While some of these patterns are unique to a person or a valley or a type of vocal music. others permeate most all of the music studied;...9

As mentioned earlier, Liv Greni in 196.0 wrote an article about the use of traditional musical formulas in the lullabies of setesdal. She pointed out that a large number of the melodies from the upper part of this valley can be reduced to variants of a limited number of melodic formulas. 5

But as yet, it appears that the full extent of centonization technique found in Norwegian vocal folk music has not been fully recognized. 6

\section{Methodology}

The purpose of this computer analysis was to examine the different motives which constitute the melody of a lullaby. Of most interest to this study are the

\footnotetext{
${ }^{3}$ The New Grove Dictionary of Music and Musicians, 1980 ed.. S.v. "Centonization," by Geoffrey Chew.

"Holman. "Centonization Technique", pp. 342-343.

5Greni, "Bånsuller i setesdal", pp. 13-28.

${ }^{6}$ Holman, "Integrating Melodic Elements and Modality in Norwegian Religious Folk Tunes," paper presented at the 25 th Conference of the International Folk Music Council, Oslo, Norway, 1979, p. 5.
} 
frequently recurring motives. However, it is also

important to notice which formulas seldom appear, or

which formulas never appear in these melodies.

The lullabies from the valleys of valdres,

Gudbrandsdalen, and Østerdalen are analyzed in the next

chapter. The analysis is organized in three parts: (1)

the representative motives of each valley, (2) a

comparison of the formulas from the different valleys,

and (3) an identification of the motives which are common

to all the valleys.

In order to assure an efficient study of the material already collected, the melodies are entered into a computer file (data base) for comparison. 7 Arranged according to collections, the tunes are given their own numbers; and the different collections are assigned an abbreviated title. All variants of melodies have an individual number. (See the list in Appendix 3 regarding numbering and abbreviations.)

According to textual or melodic patterns the

7 The Andrews University data base was initially built by professor Hans-Jørgen Holman ". . to compare the recurring melodic material of Norwegian vocal folk music with the types of melodic material that historically had been associated in one way or another with or was conceivably influential in forming the melodic inflection in this folk music. It includes, besides the Norwegian folk music, folk music of the other scandinavian countries, Lutheran chorales from Lutheran psalters used in Norway, chants from English twelfth- and thirteenth-century chant manuscripts and the Liber Usualis, vocal folk music from other Western European countries, and Troubadour and Trouvere music, . - ." (Holman, "Centonization Technique", pp. 336, 337.) 
tunes are divided into phrases ranging from 3 to 23 notes in length. The average melody consists of 4 to 5

phrases. There is a great diversity in the phrase length of many lullabies. It is not always clear where to split a melody into phrases; hence these phrases may be quite irregular in rhythm and form.

Each melody has been studied to determine its tonal center. Especially in the older lullabies, the use of ancient modality and modulations makes the task of determining a tonic difficult at times. When a tune can not be assigned to a tonality or a mode, or when a tune appears to have no tonal center, one is arbitrarily chosen for reference. With the assigned tonal center as number 1, each pitch has been given a separate number in relation to the tonal center. The octave above the tonic thus becomes number 8 , and the octave below -1 . An example of a phrase with its numbering appears in fig. 3.

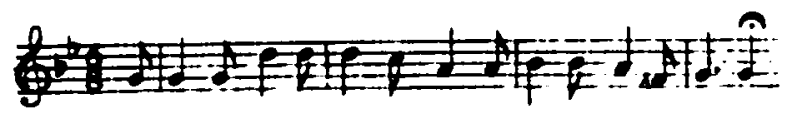

$$
\begin{array}{lllllll}
1 & 5 & 4 & 2 & 3 & 2-7 & 1
\end{array}
$$

Fig. 3. Example of a numbered phrase.

All repetition of pitches is omitted since their occurrence in the melody usually is determined by the number of syllables in the text. Since each stanza may have a different number of syllables there is a variation in the number of times the unison appear in each verse. 
Therefore, repeated pitches are not significant in the outline of the different motives. Ornaments and passing notes, however, are retained in the data base. The opening pattern of a phrase, the incipit, and the closing pattern of a phrase, the cadence, are compared with each other both untransposed and transposed.

The lullabies from the three valleys are analyzed and reported separately. In order to pinpoint differences and similarities in the melodies of the different valleys, the lullabies from each valley are compared with each other. The total number of lullabies gathered is 303. Half of these, the melodies which are to be analyzed originated from the three valleys, namely: valdres, Gudbrandsdalen, and Østerdalen, and half from collections made in other locations. The melodies from the three valleys are analyzed in detail by means of centonization and with the help of a large computer. 
CHAPTER IV

ANALYSIS OF LULLABIES FROM THE THREE VALLEYS

Lullabies Erom Valdres

The melodies from valdres constitute the largest group of the lullabies from the three valleys. Each of the seventy-two melodies is divided into an average of Eive phrases ranging from 3 to 20 notes each. There are 356 phrases altogether. Each phrase is compared acrording to the oponing jatterns of the phrases (incipits) and according to the closing patterns of the phrases (cadences). obviously, as the motivic pattern considered becomes longer, the percentage of use becomes smaller.

\section{Incipits}

Almost a fourth of the incipits in the lullabies from Valdres open with the third degree of the scale. The tonic opens only 69 incipits (19.48), and the fifth begins only $58(16.38)$.

Considering the first two notes of the incipits, 23 is the formula most frequently used; it appears in approximately one phrase out of eight. Other two-note formulas that appear almost as frequent are 35 and 15 . 
Both are used only in their untransposed form. Figures that appears only once are 45 and $2-7$. They are both transposed.

of three note incipits, 154 is the most common. It is used in almost 10 percent of the total number of phrases. Also, 1543 is used in 3.4 percent of the phrases; 15432 , in 2.5 percent; 154323 , in 1.7 percent; and 1543231 , in 1.4 percent. The formula 654 is used untransposed in twentythree phrases (6.5\%) and also acts as the beginning of several longer motives. Then 6543 appears in twentythree phrases $(6.58) ; 654312$, in fourteen phrases (3.98): and 6543123 , in ten phrases (2.88). Other series of pitches used with frequency are the ones beginning with the two-note motive 35 . Thus, 3 565 is used thirteen times $(3.7 \%): 356543$, ten times (2.88); and 3565431 , eight times (2.38). Also 354 appears in twelve phrases (3.48); and 3543 , in nine phrases $(2.58)$.

\section{Cadences}

As expected, the majority of the cadential patterns end on the tonic. Surprisingly, 38 percent of the cadential patterns end on pitches other than the tonic. The third ends 52 phrases (14.6\%), and the fifth 30 phrases $(8.48)$.

The most domineering among the cadential two-note motives is the pattern 21 . It appears untransposed in 
106 phrases $(29.88)$. Of the remaining two-note motives,

31 is used most frequently. It is employed in 59 phrases (16.68). The rest of the two-note motives appear more sporadically.

The following motives are the most frequently recurring cadential formulas in the lullabies from Valdres: 321 , used in sixty-four phrases (188): 2321 and 4321 , both used in twenty-three phrases (6.58); 12321 , used in twenty-two phrases (6.28); 312321 and 654321 , both used in ten phrases (2.88): and $\begin{array}{llllllllllllll}4 & 3 & 1 & 2 & 2 & 1\end{array}$ and 3565431 , both used in eight phrases $(2 \cdot 38)$.

\section{Lullabies from Gudbrandsdalen}

The number of lullabies from Gudbrandsdalen is forty-eight. These melodies divide into 221 phrases ranging from 4 to 19 notes in length.

\section{Incipits}

In the phrases of these lullabies the most common opening note is the tonic. It appears in 24.4 percent of the total number of phrases. The fifth which is used a little less frequently, opens 17.7 percent of the phrases, and the third opens 16.7 percent of the phrases. Al. the scale degrees within the range of an octave above the tonic appear as the opening note of a phrase: although there are a few scale degrees which are very seldom used. For instance, the seventh and the octave 
are used only twice each.

The most common two-note opening incipit is 12 . It appears thirty-one times of which twenty-five (11.38) are untransposed, and it is the opening motive of several longer formulas. The three-note motive 123 appears twenty-four times $(10.88)$. The four-note pattern 1234 appears nine times (48), while the five-note pattern 12345 appears five times (2.38). The two-note motive 54 is used nearly as often (10.58) as the motive 12 . The motive 54 frequently occurs in the longer patterns: 543 appears twelve times (5.48), and 5432 appears eleven times (58). Longer motives than these occur so seldom that they are statistically unimportant.

\section{Cadences}

Patterns used at the opening of a phrase may also appear at the close of a phrase. In 39 percent of the phrases the tonic appears at the end. Twenty-nine phrases (13.18) end on the fifth, and twenty-six phrases (11.88) end on the third. of the various scale degrees within the octave it is only the seventh that never appears. The sixth is used only once.

The most significant two-note cadential pattern

is 3 1. Untransposed it is used in thirty phrases (13.68). Appearing less frequently in its untransposed form is the motive 2 l. It is used in twenty-five phrases $(11.38)$. When the number of transposed phrases 
is added to the number of untransposed phrases, 21 appears in as many as seventy phrases (31.78). The movement of -71 is also found quite frequently; altogether it appears at the end of fifty-two phrases (23.58). Another end movement which seems to be characteristic of the lullabies from Gudbrandsdalen is the cadential pattern of $1-1$. It appears in eleven phrases (58).

The 31 pattern ends the motives of 231 (128) and $3231(3.68)$. The 21 pattern ends the motive of 321 (untransposed 88, both untransposed and transposed 178): 4321 (untransposed 3.68, both 16.48): 54321 (untransposed 18, both 3.68); and 654321 (transposed 18). The -71 pattern ends the motives of $2-71$ (untransposed 5.48, both 9.58): $32-71$ (untransposed 48, both 68); $21-71$ (untransposed 1.48, both 5.48); and $132-71$ (untransposed 2.38 , both 3.68).

\section{Lullabies from Østerdalen}

The group of lullabies from Østerdalen is the

smallest of the collections from the three valleys. It contains only thirty-four melodies which is approximately half the number of melodies found in the valdres collection. The total number of phrases in the melodies from østerdalen is 159. In length the phrases range from 3 to 23 notes each. 


\section{Incipits}

As in the lullabies from Gudbrandsdalen most of the melodies in $\varnothing s t e r d a l e n$ open with the tonic. In Østerdalen, though, the percentage of phrases in which it occurs is higher $(29.68)$. The percentage of phrases that begin on the third is 25.2 percent. Counted together, these two scale degrees open more than 50 percent of the 159 phrases. Although they do not appear as often, all other scale degrees within the octave above the tonic are used. The fifth appears in the beginning of twenty-two phrases (13.98), and the other scale degrees are used less than 6 percent each.

The two-note motive 15 opens 11 percent of the total amount of phrases. It also creates the beginning of longer motives like the series of 154 which appears twelve times $(7.68)$ and of 1543 which appears nine times $(5.78)$.

Another two-note opening motive that appears quite frequently is the motive of 12 . It is used fifteen times (9.48) altogether; twelve of these phrases (7.68) are untransposed. The three-note pattern 123 appears the same number of times.

\section{Cadences}

In almost half of the phrases the tonic is used to end the cadences. The other scale degrees appear much less frequently. of these other pitches, the third and, curiously, the dominant below the tonic are used the 
most. Each of these pitches closes 13.2 percent of the phrases. The fifth above the tonic appears at the end of 12.5 percent of the total amount of phrases.

Another characteristic of the lullabies from Østerdalen is the frequent use of the stepwise movement of -7 1 to end a phrase. Untransposed it appears twentysix times (16.48); but counting the transposed phrases as well, the movement appears as often as fifty-eight times (36.58).

The movement of 21 appears quite often. It appears in fifty phrases (31.58): however, only nineteen phrases (128) are untransposed. The motive 31 ends forty-one phrases (25.88), of which twenty (12.68) are untransposed.

When observing the longer formulas, the motives of 31 and 21 show up regularly. They are used in the patterns of 231 and 321 . The melodic figure 231 appears twenty-three times $(14.58)$. of which thirteen (8.28) are untransposed. The melodic figure 321 also appears twenty-three times $(14.58)$, of which thirteen (8.28) are untransposed. And the pattern of 431 appears fifteen times (9.48), of which only six (3.88) are untransposed.

The 321 motive is expanded into the stepwise motion of 4321 and 54321 . In all, the motive 4321 is used thitteen times (8.28) of which eight phrases (58) are untransposed. The pattern of 54321 
appears seven times (4.48) untransposed and nine times (5.78) altogether.

The movement of -71 shapes the end of several longer motives. It is expanded into the motive of $12-7$ 1, which is used twelve times (7.68) in all, but only three times (1.98) untransposed. It also ends the pattern of $32-71$, which is used six times (3.88) in its original form, and eight times (58) counting the transposed phrases. The five-note motive $132-71$ is used Eive times $(3.28)$.

Comparison of the Lullabies From the Three valleys

The total number of lullabies from the three valleys of Valdres, Gudbrandsdalen, and $\emptyset$ sterdalen is 154. These melodies are divided into 736 phrases, ranging from 3 to 23 notes in length. The average number of phrases per melody is 4.8 .

\section{Incipits}

\section{Opening note}

Whan comparing the opening notes used in the incipits of the three valleys, one observes, as expected, that the most frequently recurring pitches are the tonic, the third, and the fifth. The comparative lists in table 1 show that the use of these various pitches varies widely.

The lullabies from Gudbrandsdalen and Østerdalen use the tonic most frequently, while the majority of 
TABLE 1

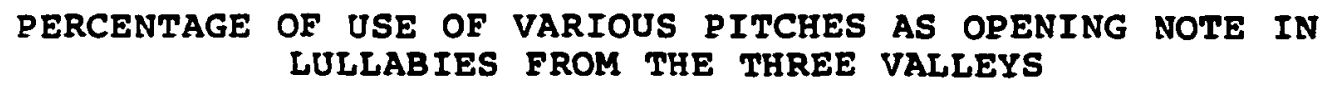

\begin{tabular}{|c|c|c|c|c|c|}
\hline \multicolumn{2}{|c|}{ valdres } & \multicolumn{2}{|c|}{ Gudbrandsdalen } & \multicolumn{2}{|c|}{ Osterdalen } \\
\hline Pitch & Percentage & Pitch & Percentage & Pitch & Percentage \\
\hline 3 & 22.8 & 1 & 24.4 & 1 & 29.6 \\
\hline 1 & 19.4 & 5 & 17.7 & 3 & 25.2 \\
\hline 5 & 16.3 & 3 & 16.7 & 5 & 13.8 \\
\hline 2 & 14.9 & 4 & 15.8 & $4 /-5$ & 6.3 \\
\hline 4 & 11.6 & $2 /-5$ & 8.2 & 2 & 5.7 \\
\hline 6 & 10.6 & -7 & 4.5 & -7 & 4.4 \\
\hline-5 & 2.8 & 6 & 3.2 & -6 & 1.9 \\
\hline-7 & 0.8 & $7 / 8$ & 0.9 & $6 / 8$ & 1.3 \\
\hline-1 & 0.6 & & & $7 /-3$ & 0.6 \\
\hline-3 & 0.3 & & & & \\
\hline
\end{tabular}


Lullabies from valdres opens with the third. The percentage of times the tonic appears in the melodies from osterdalen is almost twice the percentage of times it appears in the melodies from Valdres. It is also interesting to notice that in the incipits from osterdalen, the dominant below the tonic appears just as often as the fourth above the tonic.

In Gudbrandsdalen and Østerdalen all scale degrees within the octave above the tonic are used to open the incipits, while in valdres no incipits start with the seventh or the octave. In the octave below the tonic all valleys use the fifth and the seventh scale degree, while the third is only used in valdres and Østerdalen. The sixth below is used only in Østerdalen, and the octave below only in valdres. Except for the fifth below the tonic, no other scale degree in that octave has been used in more than 5 percent of the incipits of any valley.

Two-note motives

of the two-note motives, 23 is the most frequently recurring pattern in valdres. It appears in approximately 12 percent of the phrases, which is nearly twice the number of times it appears in the other two valleys. In Gudbrandsdalen it is used in 7 percent of the phrases, and in Østerdalen it appears in only about 2 percent of the phrases.

Another two-note motive that appears quite often 
in the lullabies of valdres is the pattern 35 . It is used forty-one times (11.58) in these melodies. In Østerdalen this pattern appears twelve times (7.58), while in Gudbrandsdalen it appears only ten times (4.58), of which eight (3.68) are untransposed.

The most noticed two-note pattern in the melodies of Dsterdalen is 15 . It opens 11.3 percent of the incipits. This motive is also used in the two other valleys; in fact, the melodies of valdres use I 5 almost as often (118); while the melodies of Gudbrandsdalen only use 15 in 5 percent of the phrases.

The most frequently used two-note motive in the Gudbrandsdal collection is 12 . Untransposed it is used in 11 percent of the phrases, while adding the transposed phrases, the percentage increases to 14 percent. The Dsterdal collection employs this motive a little less frequently. The percentage of untransposed phrases is 7.5 percent which increases to almost 10 percent after adding the transposed phrases. In valdres, however, this motive seldom is seen. Untransposed it appears in only 1.7 percent of the phrases, and totally in 3.7 percent of the phrases.

Motives special to the Iullabies Erom Valdres

The lullabies from Valdres contain long patterns. Several of these patterns are unique to this valley. This may be due to the fact that the collection of 
melodies from valdres is the largest of the three anthologies. The series of patterns beginning on 65 is quite special to the Valdres collection; and 65 appears in almost 10 percent of the incipits from valdres. In its untransposed form 65 appears in on $1 Y 1.3$ percent of the lullzbies from $\emptyset$ sterdalen and in 3 percent of the melodies from Gudbrandsdalen. The motive 653 is used in 3 percent of the lullabies from valdres, but only once does it appear in the two other collections, and then only in its transposed form. The patterns of 6534 and 65343 are not found in Gudbrandsdalen; in østerdalen it is found only once in its transposed form; but in valdres it is used in 3 percent of the phrases. The patterns of 654 and 6543 are used in 6.5 percent of the valdres melodies, but only in $1.3-3.8$ percent of the melodies from the two other valleys. Interestingly, 6531 is not found in Gudbrandsdalen, but it appears almost as frequent in østerdalen as it does in Valdres (approximately 48). The motives of 6543123 and 654321 appear only in valires (1.78). The patterns of 353,3535 , and 5343 are also unique to valdres. The three-note patterns appear in 4.5 percent of the phrases each, while the four-note pattern is used in 3.7 percent of the phrases. These patterns never appear in the collections of Gudbrandsdalen and osterdalen. 
Motives special to the Lullabies

Erom Gudbrandsdalen

In Gudbrandsdalen the series of notes beginning with 54 are the most interesting. The two-note pattern appears in approximately 10.5 percent of the melodies from this valley--twice as often as it appears in the melodies from the two other valleys. In the three-note pattern 543 , the proportions are nearly leveled out. The motive appears in 5.4 percent of the melodies from Gudbrandsdalen, in 4.5 percent of the melodies from Valdres, and in approximately 3.5 percent of the melodies from $\varnothing$ sterdalen. For the four-note pattern 5432 (used 58), though, the proportions are the same as for the pattern 54.

The stepwise motion of 1234 is another motive used in the melodies of Gudbrandsdalen (about 48), but it appears seldom in the two other valleys (about 18). The two-note pattern -51 is used seven times $(3.28)$ in the phrases of Gudbrandsdalen, but it appears only once in Dsterdalen, and two to three times in valdres.

Motives special to the Lullabies Erom 6sterdalen

Special to the melodies of Dsterdalen are a few motives that begin with the third scale degree. The twonote motive 31 is used in 6.3 percent of these melodies, while in valdres it appears on $1 y$ in a couple of melodies (approximately 18), and in Gudbrandsdalen in about 3 percent of the melodies. Intransposed the motives of 
321 and $321-7$ are used in 3.8 percent of the incipits of Østerdalen and in approximately 1.5 percent of the incipits from Gudbrandsdalen. In Valdres 321 is used in 0.8 percent of the incipits $(2.88$ counting the transposed phrases as well), but $321-7$ never appears in these lullabies. Unique to the valley of osterdalen is the five-note pattern 34564 . It appears seven times (4.48), and of these are four phrases (2.58) are untransposed.

The patterns of $-6-7$ and $-6-7 \quad 1$ appear three times (1.98), untransposed, in the lullabies of Østerdalen. These patterns are never found untransposed in the lullabies of the two other valleys. Totally they appear twelve to thirteen times (untransposed 7.58 , both untransposed and transposed 88 ) in $\varnothing$ sterdalen, but only four to seven times (untransposed 28 , both 38 ) in Gudbrandsdalen, and one to four times (untransposed 0.28 , both 18 ) in valdres. The pattern $-6-71-7$ is only found in Østerdalen (untransposed 28, both 48).

\section{Cadences}

\section{Ending note}

As expected, the majority of the lullabies from the three valleys end on the tonic. However, there is a great difference in the number of times this occurs in the three collections. Table 2 shows that in valdres, almost two-thirds of all phrases end on the tonic, while in Gudbrandsdalen, the percentage of phrases that end on 
TABLE 2

\begin{tabular}{|c|c|c|c|c|c|}
\hline \multicolumn{2}{|c|}{ Valdres } & \multicolumn{2}{|c|}{ Gudbrandsda len } & \multicolumn{2}{|c|}{ Dsterdalen } \\
\hline Pitch & Percentage & Pitch & zercentage & pitch & Percentage \\
\hline 1 & 62.1 & 1 & 39 & 1 & 42.8 \\
\hline 3 & 14.6 & 5 & 13.1 & $3 /-5$ & 13.2 \\
\hline 5 & 8.4 & 3 & 118 & 5 & 12.5 \\
\hline 2 & 7.6 & 2 & 10 & 2 & 8.8 \\
\hline-5 & 6.5 & -7 & 9.5 & -1 & 3.2 \\
\hline-7 & 0.8 & -5 & 8.6 & -7 & 2.5 \\
\hline \multirow[t]{3}{*}{-3} & 0.3 & -1 & 5.4 & -4 & 1.9 \\
\hline & & $\dot{4}$ & 2.3 & $6 / 7$ & b.6 \\
\hline & & 6 & .0 .5 & & \\
\hline
\end{tabular}


the tonic is only 39 percent. The third is used at a much lower percentage $(11.88,13.28$, and 14.68$)$. In Gudbrandsdalen, though, the use of the fifth surpasses the use of the third by more than 1 percent. In the two other valleys the fifth appears in 8.4 percent and 12.5 percent of the total amount of phrases. One fact worth noticing is the frequent use of the dominant below the tonic in the lullabies of $\emptyset$ sterdalen. This scale degree appears just as frequently at the end of a cadence as the third $(13.28)$. In valdres the dominant below the tonic is utilized only half as many times $(6.58)$ as in Dsterdalen; and in Gudbrandsdalen it is utilized slightly more than in valdres $(8.58)$.

The octave never appears at the end of a phrase. The rare appearance of the seventh is in Østerdalen. The sixth is never used at the end of a cadence in the melodies from valdres; and in the melodies from Gudbrandsdalen and $\emptyset$ sterdalen it appears only once. significantly, the fourth ends five phrases in the lullabies from Gudbrandsdalen, but none of the phrases in Valdres and Dsterdalen.

Two-note motives

Common to all three valleys is the liberal use of the two-note patterns 21,31 , and -71 . The melodies of Valdres and Gudbrandsdalen use them in this descending order of frequency, while the melodies of Østerdalen make the most use of the -7 I motive. However, the percentage 
of motivic use varies considerably. The movement of 21 is used in 40 percent (untransposed, 308 ) of the valdres melodies, in 32 percent (untransposed, 11.38) in the Gudbrandsdal melodies, and in 31.5 percent (untransposed, 208) in the $\varnothing$ sterdal melodies. The movement of -71 is used in 36.5 percent of the cadences from $\phi s t e r d a l e n$ (untransposed, 16.48), but in only 23 percent of the cadences in valdres (untransposed, 188), and in 9 percent of the cadences in Gudbrandsdalen (untransposed, 88).

Motives special to the Lutlabies Erom Valdres

The series of patterns ending on 321 is

characteristic for the melodies of Valdres. Untransposed the pattern of 321 appears in 18 percent of the phrases. That is more than twice as often as the same motive appears in Gudbrandsdalen and $\phi$ sterdalen. This characteristic is not as statistically significant when we add the number of times 321 appears transposed (Valdres, 20.58; Gudbrandsdalen, 178; and Østerdalen, $14.58)$.

The four-note pattern 2321 is found in 6 percent and 7 percent of the cadences from Valdres, whereas in the cadences from the two other valleys it appears only 1.3 percent and 3.8 percent. The five-note pattern 12321 is found in 4 percent and 5 percent of the valdres melodies, while it only appears once or twice untransposed in the melodies from the other two valleys. 
The total percentage of times the movement occurs in these valleys, though, is 2.3 percent and 3 percent. The six-note pattern 312321 is found in 3 percent of the melodies from valdres, but appears only once in each of the other two collections; and the seven note pattern 4312321 , which never appears in Osterdalen, is found once, transposed, in Gudbrandsdalen, and is used 2.3 percent in valdres. Another seven-note pattern that is found only in valdres is 3565431 . It also appears in 2.3 percent of the melodies.

Motives special to the Lullabies Erom Gudbrandsdalen

Several motives unique to Gudbrandsdalen are $1-1,21-1,321-1$, and $321-7$. The motive $1-1$ is used in 5 percent of the melodies; the other three motives in 3.2 percent of the melodies. The two patterns of $1-7$ and $31-7$ are also special to Gudbrcinsdaieñ as they appear in 3.2 percent and 6.8 percent of the melodies from this valley, whereas they appear in only 0.3 percent and 0.6 percent of the melodies from the two other valleys.

Motives special to the Lullabies Erom osterdalen

Special to the cadences of Dsterdalen are the motives 45,645 , and 65645 . The 45 motive appears in 6.9 percent of these cadences, while the other two-note motives appear in 4.4 percent each. of these 
motives the 45 motive is found in 3.6 percent of the cadences from Gudbrandsdalen, and in 2.3 percent of the cadences from valdres. The other two motives are not found in valdres, and the 645 motive appears twice in the Iullabies from Gudbrandsdalen.

The motives of $-7-5$ and $1-7-5$ are also special to østerdalen, although they do appear in the melodies from the other valleys as well. The $-7-5$ motive appears in 6.9 percent of the melodies of $\emptyset$ sterdalen, in 3.2 percent of the melodies from Gudbrandsdalen, and in 1.4 percent of the melodies from valdres. The $1-7-5$ motive is found in 4.4 percent of the cadences from Dsterdalen, in 2.3 percent of the cadences from Gudbrandsdalen, and in 0.8 percent of the cadences from valdres. 
CHAPTER $\mathrm{V}$

CONCLUSION

Common characteristics of the lullabies from the three valleys of Valdres, Gudbrandsdalen, and østerdalen include the frequent use of the tonic, the third, and the fifth in the opening and at the end of a phrase. The tonic, which is the scale degree that appears most often, opens every fourth incipit and ends as many as 50 percent of all the cadences. While the third and the fifth scale degree are not noticed as frequently at the end of a phrase (13.58 and 108$)$, they occur often at the beginning of a phrase (228 and 168$)$.

Formulas that are common to these folk melodies usually open with the two-note motives 15 (98), 35 (8.58), and 12 (transposed 68, both transposed and untransposed 88 ). Some of these most frequently repeated formulas are $123,154,1543$, and 15432 . The cadences usually end with one of these twonote patterns: 21 (untransposed 208, both 368); 31 (untransposed 158, both 238), and -71 (untransposed 108 , both 248). The 21 pattern ends two of the most frequently recurring series of motives found in the cadences of these melodies. Both series move in a 
stepwise manner. The first is the scale-like pattern of $321,4321,54321$, and 654321 ; and the second is a series of figures that moves in the compass of a third, namely: $\begin{array}{lllll}2 & 2 & 1 & 2321, \text { and } 312321 .\end{array}$ other repeated formulas are the patterns 3231 . $132-71,565431$, and 432321 , although the last two formulas never appear in the melodies from Østerdalen.

Apart from the above described normal patterns, there are certain characteristics emphasized in the lullabies from each valley. Special to the lullabies from Valdres is the frequent use of the third in the beginning of the incipits. It opens more phrases than the tonic, and is employed 10 percent more frequent $1 y$ as the opening note in valdres than in the two other valleys. The tonic, however, appears much more liberally at the end of cadences; in fact, in the cadences of valdres the tonic is used nearly twice as often as in the cadences of Gudbrandsdalen. The seventh and the octave above the tonic never appear as opening notes of the incipits of valdres, whereas they can be found, although infrequently, in the incipits of the two other valleys. The most common two-note opening figure in valdres is 23 . The figure 12 does not appear as often as in the two other valleys. The melodies from valdres utilize several motives beginning with 65 . Some of

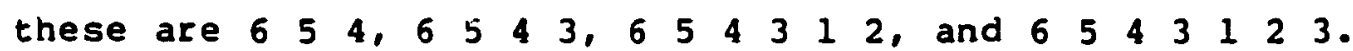


Unique to this valley are the motives 353,3535 , and 5343.

Characteristic for the lullabies from

Gudbrandsdalen is the frequent use of the fifth scale degree both in the opening and at the end of a phrase. It appears in 1 percent more phrases than the third. of two-note opening motives 54 is used nearly as frequently as 12 . Longer patterns that are often seen in these melodies are 543,5432 , and 1234 . The last motive named is seldom noticed in the other two valleys. Unique to Gudbrandsdalen are the cadential patterns of $1-1,21-1,321-1$, and $321-7$, and therefore they make an interesting identifying characteristic. special to the melodies from osteralen is the frequent use of the -5 at the end of a phrase. It appears just as often as the third scale degree (13.28). Another interesting fact is the liberal use of the tonic and the third in the opening of a phrase. These two pitches account for more than 56 percent of the opening notes in the incipits. Characteristic for the phrase beginnings of Østerdalen is the use of 31 and $321-7$. Unique to this valley is the pattern 34564 . Motives that often appear in the cadences are $12-71,32-71$. $132-71,45,645,65645,-7-5$, and $i-7-5$. Although there are many differences in the motives found in the lullabies from the three valleys, the analysis shows that there are also many similarities. 
The number of times the various motives appears in each $\forall a i l=y$ may differ, and there are certain patterns that are unique to each area, but over all, the melodies use much of the same motives.

The first, the third, and the fifth scale degree begins and ends most phrases. There is also a tendency towards stepwise and scale-like movements in the compass of a third or a fifth, sometimes with a brief visit to the sixth scale degree. The second and the third are the most frequently employed intervals, and the skip of a fifth is often noticed at the beginning of a phrase. It is interesting to compare the results of this research with the studies conducted by Liv Greni on the use of centonization within the lullabies of setesdal. Some motives which appear in the lullabies of the three valleys also exists as building blocks for the lullaby melodies in the valley of setesdal. For example, some of the most frequently employed motives in the lullabies from setesdal are the patterns $321,2-71$, and $32-71$. The motive 321 appears in 12.8 percent of the untransposed phrases in the lullabies of valdres, Gudbrandsdalen, and østerdalen; the motive $2-71$ appears in 4.5 percent of the untransposed phrases of these three valleys; and the motive $32-7$ appears in 3 percent of the untransposed phrases of these melodies. However, there are some motives from setesdal, such as the patterns 134431 and 1324431 , which never appear in 
the lullabies of the three valleys.

It is probable that similar results would be revealed as this method of analysis is applied to other folk music of Norway in search of a national inflection. A further study should be to analyze the remaining published lullabies in order to observe how they compare with the lullabies from the three valleys; to establish the use of centonization in these tunes; and to study the tonal inflection of the lullabies as a whole. It would then be possible to compare with ease the lullabies with other Norwegian vocal folk music, such as the religious folk tunes.

The analysis of the melodic structure of the lullabies Erom Valdres, Gudbrandsdalen, and Østerdalen provides one more step in determining what constitutes the "national inflection" of Norwegian folk music. The lullabies of these three principal valleys studied in this thesis form a backbone, so to speak, for understanding the great Norwegian national heritage. 
APPENDIX 1

\section{LIST OF COLLECTED LULLABIES}

Reproduced with permission of the copyright owner. Further reproduction prohibited without permission. 
1. Aurom, Magne. "Bănsuller" [Lullabies] - Liv og Lagnad: Folkeminne Era Sør-Odal. Oslo: Norsk Eolkeminnelag, 1942 .

3 lullabies: Nr. 1-3.

2. Dillan, Helge. Folkemusikk i Trondelag โFolk music in Trøndelag]. Os10: Noregs Boklag, 1972.

41 lullabies: 3and I (nr. 97-167)

$$
" \operatorname{II}(" \text {. } 55-85)
$$

3. Elling, Catharinus. Norske Eolkeviser (Norwegian folk tunesl. Christiania: Norsk Musikkforlag, 1908-25.

10 Iullabies: Hefte I (pp. 12-13)

II (P. 18)

II I (p. 15)

IV (p. 4)

$V(p, 6)$

IX (p. 3)

$\mathrm{X}$ (pp. 8, 15).

4.

- "To barneleke fra Lom" [Two children's games from Lom]. In Maal og Minne (pp. 90-91). N.p.: Bymaalslaget, 1915.

2 lullabies: Nr. 1-2.

5. - Vore folkemelodier [Our folk melodies]. Christiania: Jacob Dybwad, 1909. 3 Lullabies: Nr. 7, 9-10; pp. 61-62.

6. Gaukstad, Øystein. Toner Era Valdres [Tones from valdres]. Gjøvik: Mariendals Boktrykkeri A/S, 1973.

72 lullabies: Nr . 450-485.

7. Greni, Liv. "Bänsuller i Setesdal." Norveg

[Lullabies in setesdal. Norway] (13); Os 10:1960, pp. 13-7.8.

7 Lullabies: Eks. 3-7, 9.

8 .

- "Folkemusikk." In Norsk musikk [Folk music, Norwegian music] (pp. 32-36). Oslo: Studier i Norge, 1968 .

2 Lullabies: p. 35 .

9. "über die vokaltradition in norwegischer Volkmusik" [About the vocal tradition in Norwegian folk musicl. In Les Collogues de Wégimont vol. 1 (1954) (pp. 111-167). Paris: N.P. I1956.

4 Lullabies: pp. 156-158. 
10. Halvorsen, Tom H.: Skreslet, M.: Saeta, 0.: Tambs-Lyche, E. L.: Børresen, R.; Meyer, A. "En Undersøkelse av Bánsuller fra: Lom, Sogn, Rana, Trysil, Voss, Sor-Aurdal" [An examination of lullabies from: ... l. Musikk mellomfag [2nd degree in music], University of Oslo, 1973.

33 Lullabies: pp. 4-5, 10-14, 19-22, 26-27, $32-34$, and $37-38$.

11. Hole, A. "Sang og musikklivet i Vardal." In Varda 1 bygdebok [Song and music in vardal] (pp. 195282). Vardal: N.P., 1930 . 20 lullabies: Nr. 1-20.

12. Holt, sigurd. "Pålsdans og bånsull fra Grue." Årbok for Glămdalen [Dance and lullaby from Grue. Yearbook for Glàmdalen]. Elverum, 1946-47, p. 112 .

I lullaby: p. 112 .

13. Larsen, Rachel J. "Bănsuller $i$ levende tradisjon $i$ Soreide" [Lullabies in living tradition in Søreide]. Musikk grunnfag [lst degree in music], University of Oslo, 1974. 6 lullabies: Nr. 1-6.

14. Iindeman, Ludvig M. Aeldre og nyere norske fjeldme lodier [Earlier and more recent Norwegian mountain melodies]. Chr istiania: P. T. Malling's Forlag, 1853-67, 1907; reprint ed.. Oslo: Norsk Musikkforlag $A / S$ \& Lindemans Legat, 1983 .

11 lullabies: Bind I: Hefte 1, nr. 15-17;

$\begin{array}{lllr}n & 2, & n & 61-62 ; \\ " & n & n & 69-70 ; \\ " & 4, & n & 179-180 ; \\ n & 5, & n & 215 ; \\ 6, & n & 255 .\end{array}$

15. Paulsen, Ragnhild E. "En analyse av 5 bănsuller fra Gudbrandsdalen" [An analysis of 5 lullabies from Gudbrandsdalen]. Musikk grunnfag [lst degree in music], University of Os Lo, 1974. 6 Lullabies.

16. Sandvik, Ole M. Folkemusikk i Gudbrandsdalen [Folk music in Gudbrandsdalen]. 2nd ed. Oslo: For laget Johan Grundt Tanum, 1948. 48 lullabies: Part IV: Nr. 1-47; pp. 157-166 and $252-253$. 
17. - Østerdalsmusikken [Music of Dsterdalen]. Os lo: For laget Johan Grundt Tanum, 1943; reprint ed., Oslo: Noregs Boklag, 1979. 34 Iullabies: Part IV: Nr . 1-30; pp. 156-157.

All variants have an individua 1 number. In three

lullabies a second verse is included, these verses have also been given an individual number. 
APPENDIX 2

SUPPLEMENTARY INFORMATION OF KNOWN PUBLISHED LULLABIES

Reproduced with permission of the copyright owner. Further reproduction prohibited without permission. 
1. Ágotnes, Jacob. "Norske barnerim" [Norwegian

children's rhymes]. Musikk hovedfag [3rd degree

in musicl. University of os 10, 1968.

2. Bjбrndal, Arne. Folkemusikk [Folk music]. Sogn: 1937.

3. Elling, Catharinus. Norske Folkemelodier: Slaatter og

Baansuller $0 . s . v$. bearbejdet for violin og

Piano INorwegian folk melodies: Dances and

IuIIabies etc. adapted for violin and pianol. Kristiania: 1919.

4. Lindeman, Ludvig M. Aeldre og nyere norske

Ejeldmelodier [Earlier and more recent

Norwegian mountain melodies]. Christiania:

P. T. Malling's Forlag, 1853-67, 1967; reprint

ed.. Oslo: Norsk Musikkforlag A/S \& Lindemans

Legat, 1983.

6 Iullabies: Bind II: Hefte $2, n r \cdot 344,370$;

$$
\begin{array}{r}
3 \text { and } 4, \text { nr. } 393, \\
n \text { " } 59{ }^{\prime} \text {; }
\end{array}
$$

"III: " 1, ne. 589.

5. Støylen, Bernt. Norske barnerim og leikar [Norwegian children's rhymes and games]. Kristiania: 1899 .

In addition to these collections there are a

couple of books on children's rhymes, etc.., from

Rogaland, and a few lullabies from Nordmøre. 
APPENDIX 3

ABREVIATION AND NUMBERING OF ANALYZED LULLABIES

Reproduced with permission of the copyright owner. Further reproduction prohibited without permission. 
1. Gaukstad, øystein. Toner fra Valdres [Tones from valdres]. Gjøvik: Mariendals Boktrykkeri A/S, 1973.

72 lullabies: Nr * 450-485.

Abbreviated title: GauTVB. Numbering: 106083-100154.

2. Sandvik, Ole M. Folkemusikk i Gudbrandsdalen [Folk music in Gudbrandsdalen]. 2nd ed. Oslo: For laget Johan Grundt Tanum, 1948. 48 Iullabies: Part IV: Nr. 1-47; pp. 157-166 and 252-253.

Abbreviated title: SanFG4B. Numbering: $100001-100048$.

3. - Østerdalsmusikken [Music of Dsterdalen]. Oslo: For laget Johan Grundt Tanum, 1943; reprint ed., Oslo: Noregs Boklag, 1979. 34 Iullabies: Part IV: Nr. 1-30; pp. 150-157.

Abbreviated title: SanOEM. Numbering: 106049-100082. 
SELECTED BIBLIOGRAPHY

Reproduced with permission of the copyright owner. Further reproduction prohibited without permission. 


\section{SELECTED BIBLIOGRAPHY}

\section{Books}

Bjørndal, Arne. Norsk Folkemusikk [Norwegian folk music]. Bergen: A.S Lunde \& Co. Forlag, 1952.

Dillan, Helge. Folkemusikk i Trøndelag lFolk music in Trфndelag]. Oslo: Horegs Boklag, 1972.

Elling, Catharinus. Norske folkeviser [Norwegian folk tunes]. Christiania: Norsk Musikkforlag, 1908-25.

- Norsk folkemusikk [Norwegian folk music]. Kr is tiania: Steenske Boktrykkeri Johannes Bjornstad, 1922 .

- Vore folkemelodier [Our folk melodies]. Christiania: Jacob Dybwad, 1909.

Gaukstad, Đystein. Toner fra Valdres [Tones from Valdres]. Gjovik: Mariendals Boktrykkeri A/S, 1973.

Huldt-Nystrøm, Hampus. Det nasjonale tonefall [The national inflection]. Oslo: Universitetsforlaget, 1966 .

Kortsen, Bjarne. 77 Norwegian Lullabies according to Dr. O. M. sandvik. Bergen: By the Author, Solbakken 17. 5006 Bergen, 1970 .

Ledang, Ole $K$. Song syngemáte og stemmekarakter [Song, song style and song characteristics]. Oslo: Universitetsfor laget, 1967.

Lindeman, Ludvig M. Aeldre og nyere norske fjeldmelodier [Earlier and more recent Norwegian mountain melodies] . Christiania: P. T. Malling's Forlag, 1853-67, 1907: reprint ed., Oslo: Norsk Musikkforlag A/S Lindemans Legat, 1983.

Sandvik, ole M. Folkemusikk i Gudbrandsdaien [Folk music in Gudbrandsdalen]. 2nd ed. Os10: Forlaget Johan Grundt Tanum, 1948 .

- Norsk folkemusikk [Norwegian folk music]. Kristiania: Steenske for lag, 1921. 
- Østerdalsmusikken [Music of Østerdalen]. Oslo: For laget Johan Grundt Tanum, 1943; reprint ed.. Oslo: Noregs Boklag, 1979.

\section{Articles}

Aurom, Magne. "Bănsuller" [Lullabies] - Liv og lagnad: Folkeminne fra Sør-Odal. Oslo: Norsk folkeminnelag, 1942.

Bakke, Arnt. "Folkemusikk i Nord-Norge." Ottar: Populaere smăskrifter fra Tromsø Museum [Folk music in north Of Norway. Ottar: Popular journals from Tromsø Museum) 13/2 (March 1957): 3-9.

Elling, Catharinus. "To barneleke Era Lom" [Two children's games from Lom]. In Maal og Minne (p. 90-91). N.P.: Bymaalslaget, 1915.

Greni, Liv. "Bånsuller i Setesdal." Norveg [Lullabies in Setesdal. Norway] 7 (13); Oslo:1960, pp. 13-28.

- "Folkemusikk." In Norsk musikk [Folk music, Norwegian music] (pp. 32-36). OsI0: studier i Norge, 1968 .

- "über die Vokaltradition in norwegischer Volkmusik" [About the vocal tradition in Norwegian folk music]. In Les Collogues de Wégimont vol. 1 (1954) (pp. 111-167). Paris: N.p.. 1956.

Hole, A. "Sang og musikklivet i Varda $1 . "$ In Vardal bygdebok [Song and music in Vardal] (pp. 195-202). Varda1: 1930 .

Holman, Hans-Jorgen. "Centonization Technique in the Vocal Folk Music of Norway." Michigan Academician 15 (Spring 1983) : 333-345.

HolŁ, Sigurd. "Pålsdans og bânsull fra Grue." Ârbok for Glămdalen [Dance and lullaby from Grue. Yearbook For Glámdalen]. Elverum, 1946-47, p. 112 .

The New Grove Dictionary of Music and Musicians, $1980 \mathrm{ed}$. S.y. "Centonization:" by Geoffrey Chew.

Ibid. S.v. "NorwaylII: Folk Music," by Reidar Sevåg. 


\section{Theses and other papers}

Halvorsen, Tom H.: Skreslet, M.; Saeta, O.; Tambs-Lyche, E. L.: Børresen, R.; Meyer, A. "En undersøkelse av bănsuller fra: Lom, Sogn, Rana, Trysil, Voss, SorAurdal" [An examination of lullabies from: ... ]. Musikk mellomfag [2nd degree in music], Iniversity of Oslo, 1973.

Holman, Hans-Jørgen. "Integrating Melodic Elements and Modality in Norwegian Religious Folk Tunes." Paper presented at the $25 \mathrm{th}$ Conference of the International Folk Music Council, Oslo, Norway, 1979.

Larsen, Rachel $\mathrm{J}$. "Bảnsuller $i$ levende tradisjon $i$ søreide" [Lullabies in living tradition in Søreide]. Musikk grunnfag [lst degree in music], University of Oslo, 1974.

Paulsen, Ragnhild E. "En analyse av 5 bănsuller fra Gudbrandsdalen" [An analysis of 5 lullabies from Gudbrandsdalen]. Musikk grunnfag [lst degree in musicl, University of os 10, 1974. 